\title{
A new record of the non-native fish species Butis koilomatodon (Bleeker 1849) (Teleostei: Eleotridae) for southeastern Brazil
}

\author{
Riguel Feltrin Contente * \\ Marina Rito Brenha-Nunes \\ Carolina Correia Siliprandi \\ Rafael Andrei Lamas \\ Valeria R. M. Conversani \\ Instituto Oceanográfico, Universidade de São Paulo \\ Praça do Oceanográfico, 191, CEP 05508-120, São Paulo - SP, Brazil \\ Universidade de São Paulo, São Paulo - SP, Brazil \\ * Corresponding author \\ riguel@usp.br
}

Submetido em 12/08/2015

Aceito para publicação em 22/02/2016

\section{Resumo}

Novo registro do peixe invasor Butis koilomatodon (Bleeker 1849) (Teleostei: Eleotridae) no sudeste do Brasil. Neste trabalho, reportamos o segundo registro do peixe invasor, Butis koilomatodon, na costa de São Paulo (Sudeste do Brasil), o que representa, também, o registro mais ao sul no sudoeste do Oceano Atlântico. Discutimos os riscos de uma potencial invasão mediada pelos impactos antrópicos na área de ocorrência.

Palavras-chave: Água de lastro; Bioincrustação; Espécie exótica; Expansão portuária

\section{Abstract}

This work reports the second record of the Indo-Pacific invasive mud sleeper, Butis koilomatodon, for coastal São Paulo in southeastern Brazil, and represents the southernmost record for this species in the southwestern Atlantic Ocean. The risks of a potential invasion mediated by anthropogenic impacts on the area of occurrence are also discussed.

Key words: Alien species; Ballast water; Biofouling; Port expansion

Biological invasions are one of the most significant threats to biodiversity (VITULE; PRODOCIMO, 2012), leading to native species extinctions (CLAVERO; GARCÍA-BERTHOU, 2005), homogenization of regional biodiversity (VITULE, 2009), extirpation of ecosystem functioning (BAXTER et al., 2004) and drastic socio-economic losses (RICCIARDI et al., 2011). Recording species in non-native areas is the first step in the process of preventing invasions or mitigating their consequences (VITULE, 2009). 
Worldwide, Gobiiformes (e.g., Eleotridae and Gobiidae, sensu WILEY; JOHNSON, 2010) represents a large number of marine fish that can be invasive because they are highly capable of ship-mediated dispersal. Most of this order can live in the biofouling matter of the hull and ballast water tanks of cargo ships, which generally leads to global dispersal (WONHAM et al., 2000; LASSO-ALCALÁ et al., 2005; LOEBMANN et al., 2010; MACIEIRA et al., 2012).

The mud sleeper, Butis koilomatodon (Bleeker 1849) (Eleotridae), is native to the Indo-Western Pacific and typically lives in intertidal habitats. The first record of this species for the Atlantic Ocean was in 1972 in the Panama Canal (DAWSON, 1973). Subsequently, it has been recorded for the West African coast (MILLER et al., 1989) and the southwestern Atlantic Ocean coast, where it has been found in Venezuela (LASSO-ALCALÁ et al., 2005) and from northern to southeastern Brazil (LOEBMANN et al., 2010; MACIEIRA et al., 2012). It is speculated that the species was introduced by way of ballast water and biofouling material (LOEBMANN et al., 2010; MACIEIRA et al., 2012).

This work reports a new record of $B$. koilomatodon for coastal São Paulo, in southeastern Brazil, which represents a southern expansion of the distribution of the species in the western Atlantic Ocean.
The specimen (Figure 1) was captured on 10 August 2014 (austral winter), during a tide pool fish survey in Araçá Bay $\left(23^{\circ} 48.874 \mathrm{~S}, 4^{\circ} 24.322 \mathrm{~W}\right.$, São Sebastião Channel, northern coast of São Paulo State; Figure 2). Araçá Bay constitutes a sandy mud tidal flat that is adjacent to the International São Sebastião Port and PETROBRAS (Brazilian Petroleum) oil and gas terminal (Figure 2; see Amaral et al. [2010], for details of the Araçá ecosystem). The area surrounding the bay is highly anthropized.

For the habitat description, the following physical attributes of the pool were characterized: area (using the image program ImageJ from photographs taken about one meter from bottom); perimeter (meter tape, precision $1 \mathrm{~mm}$ ); four depth measurements (meter tape, precision $1 \mathrm{~mm}$ ); volume (mean depth $\mathrm{x}$ area); type of benthic habitat, sediment and algae cover (\%); and physical-chemical variables of the water, including four measurements of temperature $\left({ }^{\circ} \mathrm{C}\right.$, precision $\left.0.1^{\circ} \mathrm{C}\right)$, dissolved oxygen $(\mathrm{mg} / \mathrm{L}$, precision $0.01 \mathrm{mg} / \mathrm{L}$, with a Instrutherm MO-900 dissolved oxygen meter) and salinity (with a refractometer, precision $1 \mathrm{psu}$ ). The characterization of the habitat was also compared to previous studies that describe the habitat of the species (Table 1).

FIGURE 1: Individual of Butis koilomatodon (Bleeker 1849) captured in Araçá Bay (southeastern coast of Brazil).

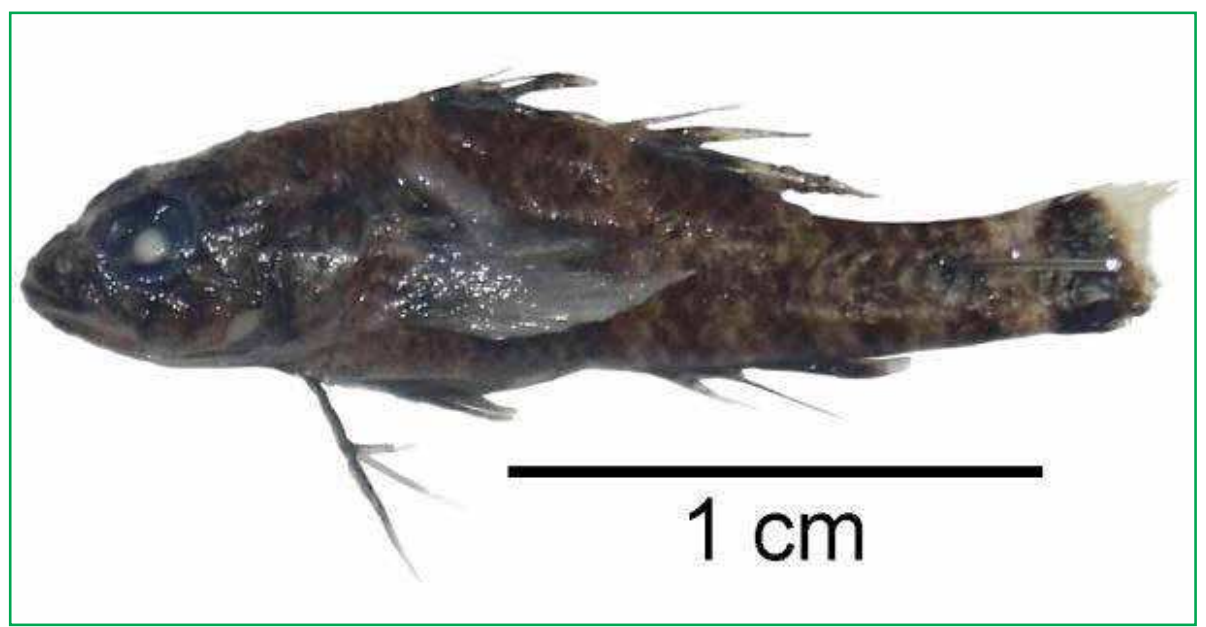


FIGURE 2: Map of South America (source: Creative Commons Attribution-Noncommercial license. (C) 2008, Erin Dill) and, in detail, the São Sebastião Channel (southeastern coast of Brazil) and Araça Bay (source: Google Earth). A = Location in Araçá Bay where Butis koilomatodon was captured. Map modified from Contente et al. (2015).

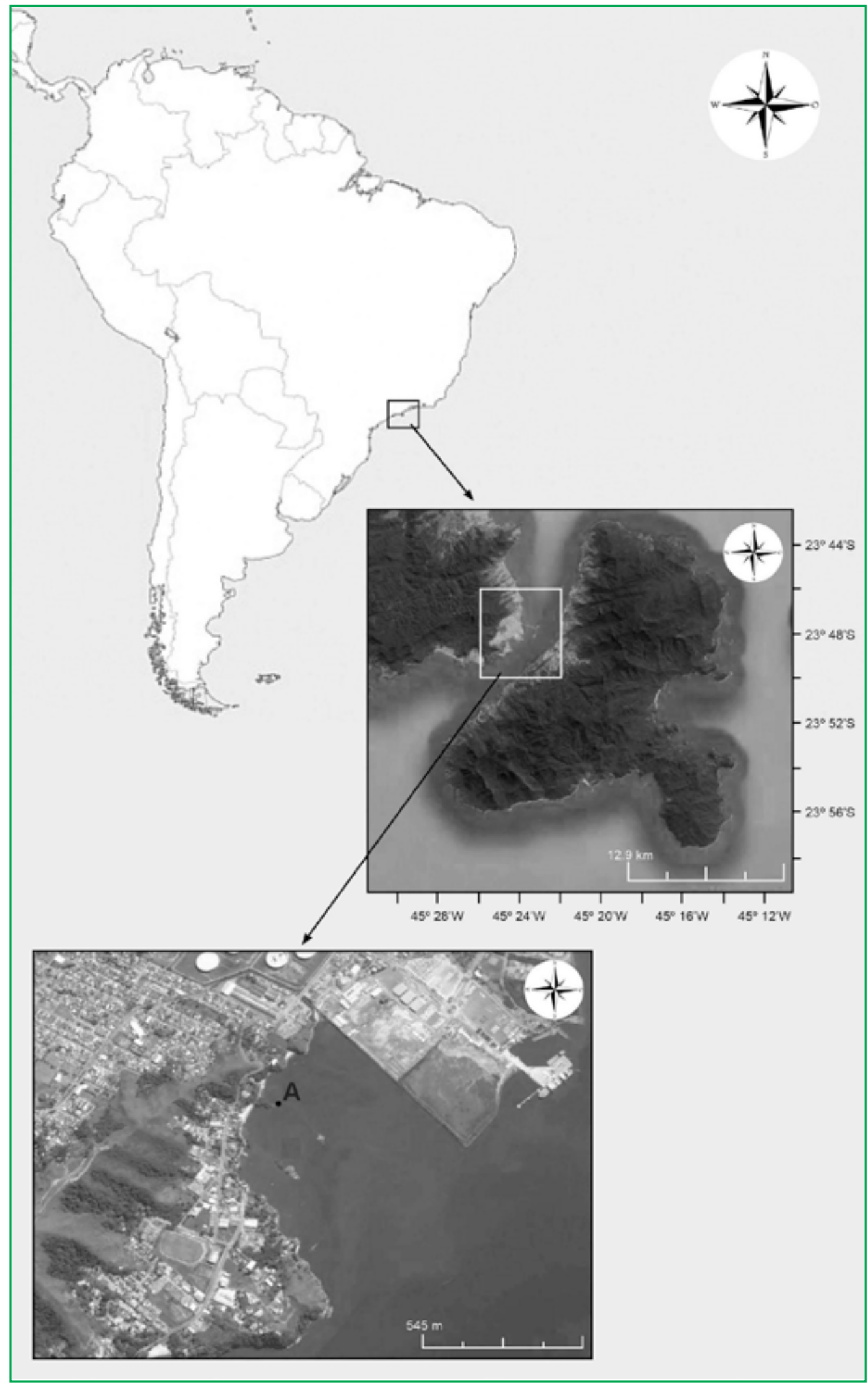


TABLE 1: Records of Butis koilomatodon from different localities and respective data of habitat characteristics, water temperature (T) and salinity (S).

\begin{tabular}{lllcc}
\hline \multicolumn{1}{c}{ Source } & \multicolumn{1}{c}{ Locality } & \multicolumn{1}{c}{ Habitat } & T $\left({ }^{\circ} \mathbf{C}\right)$ & S \\
\hline Miller et al. (1989) & Port Harcourt - Nigeria & Subtidal biofouling of port structure & $27-31$ & $27-31$ \\
\hline Miller et al. (1989) & Port Harcourt - Nigeria & Mangrove intertidal drainage channel & $26-32$ & $3.8-21.4$ \\
\hline Smith (1958) & Delagoa Bay - Mozambique & Among stones in intertidal habitats far from the sea & - & - \\
\hline Whitley (1939) & Melville Island - Australia & Invertebrate burrows in mud-tidal flat & - & - \\
\hline Dawson (1973) & Miraflores Lake - Pacific & Mud subtidal bottom of shipping channel & - & 20 \\
\hline Macieira et al. (2012) & Curuçá - N Brazil & Mud bottom & - & 31.3 \\
\hline Macieira et al. (2012) & Escuro River - SE Brazil & Algae attached to mangrove roots & - & $11-27$ \\
\hline Soares et al. (2012) & Pará - N Brazil & Rock tide pools & $28-36.9$ & $9-26$ \\
\hline
\end{tabular}

The fish was caught with a hand-net, after dissolving a clove oil solution ( $4 \%$ in alcohol) in the pools, and then preserved in formalin (4\%). Butis koilomatodon was identified using Miller et al. (1989) and Macieira et al. (2012). Meristic and morphological data, total length (TL), standard length (SL) and the weight of the specimen, were taken. The animal was not sexed. The capture and transport of the fish was authorized by the Chico Mendes Institute for Biodiversity Conservation (permit $n^{\circ} 5574607$ ) and approved by the Ethics Committee of the Oceanographic Institute at the University of São Paulo.

The meristic and morphological data of the specimen of B. koilomatodon were the following: D VI +9 , A I +8 , and P 21; serrated process on the snout; and seven regular bands on the body. The individual measured $24 \mathrm{~mm}$ TL, $20 \mathrm{~mm}$ SL and weighed $0.18 \mathrm{~g}$. The specimen was deposited in the collection of the Zoology Museum of the University of São Paulo (voucher code MZUSP 115281).

The habitat was a sand-bottom pool, formed around rock outcrops, with $75 \%$ algae cover. Litter (e.g., plastic bags, parts of planks, bottles, building rubble) and mangrove leaf litter were also present in the pools. Butis koilomatodon was captured with the following native species: Bathygobius soporator $(\mathrm{n}=14$ individuals) and Ctenogobius boleosoma $(\mathrm{n}=3)$. The pool where $B$. koilomatodon was captured had the following: area $=1.35 \mathrm{~m}^{2}$, perimeter $=13.15 \mathrm{~m}$, mean depth $=0.04$ $\mathrm{m} \pm 0.01 \mathrm{SD}$ (standard deviation), volume $=0.052 \mathrm{~m}^{3}$, temperature $=25.90^{\circ} \mathrm{C} \pm 0.48 \mathrm{SD}$, dissolved oxygen $=$ $5.10 \mathrm{mg} / \mathrm{L} \pm 0.72 \mathrm{SD}$ and salinity $=37.25 \pm 0.50 \mathrm{SD}$. The species was found in a cryptic benthic habitat, which occurs in both their native and other non-native habitats (Table 1). In addition, the specimen was captured in the greatest salinity ever reported for the species, and the water temperature was within previously reported ranges (Table 1).

Most likely the $20 \mathrm{~mm}$ SL individual was a juvenile because Macieira et al. (2012) classified juvenile individuals of B. koilomatodon as ranging from 12.8 to $33.1 \mathrm{~mm}$ SL. This individual may have come from the Escuro River (Ubatuba), located about $40 \mathrm{~km}$ north of Araçá Bay, where the species was detected in 2000 (MACIEIRA et al., 2012). A southward larval migration may have been favored by southward flowing, near-shore currents of the region (CASTRO, 2014). However, to date, it is not known if there is an established population of this species in the Escuro River. Alternatively, the new record may be linked to biofouling and ballast water of ships, which has been proposed as the cause of introduction of the species elsewhere in the world (e.g., Panama - DAWSON, 1973; Nigeria - MILLER et al., 1989; northern Brazil - SOARES et al., 2012). The species inhabits a wide array of habitats that have burrows and refuges (i.e., cryptic benthic habitats), such as biofouling (Table 1). The heavy cargo ship traffic adjacent to the bay may have favored the species' introduction.

Besides the ability to use different cryptic benthic habitats, B. koilomatodon appears to tolerate a wide 
range of salinity, withstanding oligohaline conditions (3.8; MILLER et al. 1989) to salinity as high as 37 (this study). Such attributes are most likely strongly linked to the invasive success of this species worldwide (WONHAM et al., 2000).

In addition to describing the invading ability of this species, it is also important to identify and understand the consequences of anthropogenic changes that facilitate invasions in ecosystems, which can help prevent new invasions and mitigate the impacts of establishing populations (SIMBERLOFF et al., 2013). Araçá Bay is especially vulnerable to the establishment of such a potentially highly invasive species due to the following natural characteristics and human activities: (I) the bay is a large intertidal flat with a large amount and diversity of human-created habitats (i.e., litter) for cryptic fishes, such as wooden boards, PVC pipes, plastic bags, and PET bottles; (II) the bay has salinity and temperature ranges that this species can tolerate; and (III) the bay is adjacent to ports with heavy cargo ship traffic (i.e., a potential entry route/source for new individuals) with an intensity (in tonnage/year) that is expected to increase exponentially when the projected expansion of São Sebastião Port is completed (MIRANDA, 2010).

With a relatively small sampling effort (four surveys; BRENHA-NUNES et al., unpublished data) we detected two non-indigenous species in Araçá Bay, $B$. koilomatodon and the blenny Omobranchus punctatus (CONTENTE et al., 2015). This high occurrence rate and intense ship traffic may be an indication that the bay is under high propagule pressure. If so, such a pressure is likely to cause the ecosystem to become more unstable and more susceptible to new invasions (RICCIARDI, 2005). Moreover, the presence of more than one non-native species is particularly worrying because it is thought that they mutually facilitate their abilities to survive, which could increase the magnitude of the impact (SIMBERLOFF; VON HOLLE, 1999).

Like B. koilomatodon (MACIEIRA et al., 2012), the coexistent native goby $B$. soporator is also a cryptic benthic carnivorous fish, which preys on small fish and crustaceans (CORREA; UIEDA, 2007), and the potential population establishment of B. koilomatodon in the area could lead to competition between these two species that occur in similar niches (MACIEIRA et al., 2012; SOARES et al. 2012; RICCIARDI et al., 2013). After population establishment, invasive species usually outcompete ecologically equivalent native species when resources are limited (RICCIARDI et al., 2013), leading to the decline or extinction of native populations, which drastically changes local ecological interactions and ecosystem processes (RICCIARDI et al., 2013). Bathygobius soporator may play a key ecological role in the local tide pools due to its large abundance (BRENHA-NUNES et al., unpublished data); therefore, an eventual replacement of $B$. soporator by $B$. koilomatodon would cause relevant changes in ecological processes of local tidal pools.

Solid information on reproduction, life history (e.g., spawning locations, ways of larval dispersion, maturation season), physiology and feeding ecology of the alien fish species is critical for supporting eventual monitoring and population control programs, as well as robust estimates of the impact of this species on native fish populations (SAKAI et al., 2001; SIESA et al., 2014). Unfortunately, with exception to a few aspects of natural history (e.g., this study, Table 1), this information for $B$. koilomatodon in non-indigenous areas, such as Araçá Bay, is unavailable and should be urgently studied. Particularly for Araçá Bay, a sampling program using the same study protocol for monitoring new records, occupancy patterns, density and/or reproductive parameters of the species is strongly recommended during and after the port expansion (RICCIARDI et al., 2011). This will support measures to prevent new occurrences as well as to control or eradicate the species before eventual population growth.

\section{Acknowledgments}

The authors thank Carmen Rossi-Wongtschowski for reviewing the manuscript, Alexandre Arackawa for editing the photo of the specimen, the Laboratory of Ichthyology and Growth's team, Neemias Borges and Marcelo Alves for the fieldwork, the Center of Marine Biology at the University of São Paulo for granting us the use of the laboratories, the São Paulo Research Foundation (FAPESP) for the financial support 
(Thematic Project Biota-FAPESP: no 2011/50317-5; R. F. Contente: no 2013/19435-7; C.C. Siliprandi: no 2014/20323-1), and the National Council for Scientific and Technological Development (CNPq) for the master's degree grant awarded to M. R. Brenha-Nunes (no 162503/2013-0).

\section{References}

AMARAL,A. C. Z.; MIGOTTO, A. E.; TURRA, A.; SCHAEFFERNOVELLI, Y. Araçá: biodiversidade, impactos e ameaças. Biota Neotropica, Campinas, v. 10, n. 1, p. 1-47, 2010.

BAXTER, C. V.; FAUSCH, K. D.; MURAKAMI, M.; CHAPMAN, P. L. Fish invasion restructures stream and forest food webs by interrupting reciprocal prey subsides. Ecology, New York, v. 85, n. 10 , p. 2656-2663, 2004.

CASTRO, B. M. Summer/winter stratification variability in the central part of the South Brazil Bight. Continental Shelf Research, Oxford, v. 89, p. 15-23, 2014.

CLAVERO, M.; GARCÍA-BERTHOU, E. Invasive species are a leading cause of animal extinctions. Trends in Ecology and Evolution, Cambridge, v. 20, n. 3, p. 110, 2005.

CONTENTE, R. F.; BRENHA-NUNES, M. R.; SILIPRANDI, C. C.; LAMAS, R. A.; CONVERSANI, V. R. M. Occurrence of the non-indigenous Omobranchus punctatus (Blenniidae) on the São Paulo coast, South-Eastern Brazil. Marine Biodiversity Records, Cambrigde, v. 8, e73, p. 1-4, 2015.

CORREA, M. O. D. A.; UIEDA, V. S. Diet of the ichthyofauna associated with marginal vegetation of a mangrove forest in southeastern Brazil. Iheringia, Porto Alegre, v. 97, n. 4, p. 486-497, 2007.

DAWSON, C. E. Occurrence of an exotic Eleotrid fish in Panamá with discussion of probable origin and mode of introduction. Copeia, Lawrence, v. 1, p. 141-144, 1973.

LASSO-ALCALÁ, O. M.; LASSO, C.; PEZOLD, F.; SMITH M. L. The mud sleeper Butis koilomatodon (Pisces: Eleotridae): first record from the Western Central Atlantic. Revista de Biología Tropical, San José, v. 53, n. 1-2, p. 211, 2005.

LOEBMANN, D.; MAI, A. C. G.; LEE, J. T. The invasion of five alien species in the Delta do Parnaíba Environmental Protection Area, Northeastern Brazil. Revista de Biología Tropical, San José, v. 58, n. 3, p. 909-923, 2010.

MACIEIRA, R. M.; GIARRIZZO, T.; GASPARINI, J. L.; SAZIMA, I. Geographic expansion of the invasive mud sleeper Butis koilomatodon (Perciformes: Eleotridae) in the western Atlantic Ocean. Journal of Fish Biology, Malden, v. 81, p. 308313, 2012.

MILLER, P. J.; WRIGHT, J.; WONGRAT, P. An Indo-Pacific goby (Teleostei: Gobioidei) from West Africa, with systematic notes on Butis and related eleotridine genera. Journal of Natural History, London, v. 23, n. 2, p. 311-324, 1989.

MIRANDA, Z. I. Sociedade, ecologia, economia e mudanças climáticas no litoral paulista. In: ENCONTRO NACIONAL DA ANPPAS, V, 2010, Florianópolis. Anais... Florianópolis: PROCAM, 2010. p. 1-20.
RICCIARDI, A. Facilitation and synergistic interactions between introduced aquatic species. In: MOONEY, H. A.; MACK, R. N.; MCNEELY, J. A.; NEVILLE, L. E.; SCHEI P. J.; WAAGE, J. K. (Ed.). Invasive alien species a new synthesis. Washington: Island Press, 2005. p. 162-178.

RICCIARDI, A.; HOOPES, M. F.; MARCHETTI, M. P.; LOCKWOOD, J. L. Progress toward understanding the ecological impacts of nonnative species. Ecological Monographs, Washington, v. 83, n. 3, p. 263-282, 2013.

RICCIARDI, A. R.; PALMER, M. E.; YAN, N. D. Should biological invasions be managed as natural disasters? BioScience, Oxford, v. 61, n. 4, p. 312-317, 2011.

SAKAI, A. K.; ALLENDORF, F. W.; HOLT, J. S.; LODGE, D. M.; MOLOFSKY, J.; WITH, K. A.; BAUGHMAN, S.; CABIN, R. J.; COHEN, J. E.; ELLSTRAND, N. C.; MCCAULEY, D. E.; O'NEIL, P.; PARKER, I. M.; THOMPSON, J. N.; WELLER, S. G. The population biology of invasive species. Annual Review of Ecology and Systematics, Palo Alto, v. 32, p. 305-332, 2001.

SIESA, M. E.; PADOA-SCHIOPPA, E.; OTT, J.; BERNARDI, F.; FICETOLA, G. F. Assessing the consequences of biological invasions on species with complex life cycles: Impact of the alien caryfish Procambarus clarkii on Odonata. Ecological Indicators, Amsterdam, v. 46, p. 70-77, 2014.

SIMBERLOFF, D.; MARTIN, J. L.; GENOVESI, P.; MARIS, V.; WARDLE, D. A.; ARONSON, J.; COURCHAMP, F.; GALIL, B.; GARCÍA-BERTHOU, E.; PASCAL, M.; PYSEK, P.; SOUSA, R.; TABACCHI, E.; VILÀ, M. Impacts of biological invasions: what's what and the way forward. Trends in Ecology and Evolution, Cambridge, v. 28, n. 1, p. 58-66, 2013.

SIMBERLOFF, D.; VON HOLLE, B. Positive interactions of no indigenous species: Invasional meltdown? Biological Invasions, Dordrecht, v. 1, p. 21-32, 1999.

SMITH, J. L. B. Fishes of the family Eleotridae in the western Indian Ocean. Ichthyological Bulletin of the J. L. B. Smith Institute of Ichthyology, Grahamstown, v. 11, p. 137-163, 1958.

SOARES, B. E.; RUFFEIL, T. O. B.; MONTAG, L. F. A. Occurrence of the non-native sleeper Butis koilomatodon (Bleeker, 1849) (Perciformes: Eleotridae) in the Amazon coastal zone, Brazil. BioInvasions Records, Helsinki, v. 1, n. 2, p. 95-99, 2012.

VITULE, J. R. S. Introdução de peixes em ecossistemas continentais brasileiros: revisão, comentários e sugestões de ações contra o inimigo quase invisível. Neotropical Biology And Conservation, São Leopoldo, v. 4, p. 111-122, 2009.

VITULE, J. R. S.; PRODOCIMO, V. Introdução de espécies não nativas e invasões biológicas. Estudos de Biologia, Ambiente e Diversidade, Curitiba, v. 34, p. 225-237, 2012.

WHITLEY, G. P. A new fish of the genus Prionobutis, from Northern Australia. Memoirs of Queensland Museum, Queensland, v. 11, p. 296-298, 1939.

WILEY, E. O.; JOHNSON, G. D. A. Teleosts classification based on monophyletic groups. In: NELSON, J. S.; SCHULTZE, H. P.; WILSON, M. V. H. (Ed.). Origin and phylogenetic interrelationships of Teleosts. München: Verlag Dr. Friedrich Pfeil. 2010. p. 123-182.

WONHAM, M. J.; CARLTON, J. T.; RUIZ, G. M.; SMITH, L. D. Fish and ships: relating dispersal frequency to success in biological invasions. Marine Biology, Berlin, v. 136, p. 1111-1121, 2000. 